\title{
IMPLEMENTATION OF GOVERNMENT ASSET MANAGEMENT USING TERRESTRIAL LASER SCANNER (TLS) AS PART OF BUILDING INFORMATION MODELLING (BIM)
}

\author{
ASEP YUSUP SAPTARI, S. HENDRIATININGSIH, DONY BAGASKARA, \\ AND LEVANA APRIANI" \\ Surveying and Cadastre Research Group, Geodesy and Geomatics Engineering, \\ Faculty of Earth Science and Technology, Bandung Institute of Technology, \\ Bandung, Indonesia.. \\ *Corresponding author: aprianilevana@gmail.com

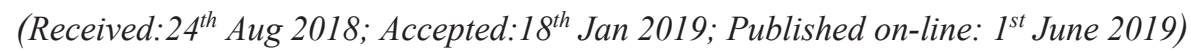 \\ https://doi.org/10.31436/iiumej.v20i1.987
}

\begin{abstract}
Building asset management is a system for organizing building assets in order to provide information to support decision making. One part of asset management is the inventory of building assets. Asset inventory can be done based on Building Information Modelling (BIM). BIM is one of the approaches to look at the building as a large unified database that can provide different information. The research case is the inventory of local government assets, especially state university assets because in Indonesia, state university assets belong to local government assets. The first step of local government asset inventory is to do three-dimensional modelling using a terrestrial laser scanner (TLS) assisted by Autodesk Revit. A textual database is created which contains the location code and item code on the asset referring to the Regulation of the Minister of the Home Affairs Number 108 Year 2016 on the Classification and Codification of Regional Property. The database is directly integrated with the threedimensional model of the building. By doing these two things, there will be a building asset management process that is integrated with BIM and can be used to plan asset development.
\end{abstract}

ABSTRAK: Pengurusan aset bangunan adalah sistem untuk menganjurkan aset bangunan untuk memberikan maklumat untuk menyokong pengambilan keputusan. Satu bahagian pengurusan aset adalah inventori aset bangunan. Penyediaan aset boleh dilakukan berdasarkan Pemodelan Maklumat Bangunan (BIM). BIM adalah salah satu pendekatan untuk melihat bangunan sebagai pangkalan data bersatu yang besar yang dapat memberikan maklumat yang berbeza. Kes penyelidikan adalah untuk inventori aset kerajaan tempatan, terutamanya aset universiti negeri, kerana di Indonesia, aset universiti negeri adalah milik aset pemerintah daerah. Langkah pertama inventori aset kerajaan tempatan adalah melakukan pemodelan tiga dimensi menggunakan pengimbas laser bumi (TLS) yang dibantu oleh Autodesk Revit. Pangkalan data teks dicipta yang mengandungi kod lokasi dan kod item aset yang merujuk kepada Peraturan Menteri Dalam Negeri Nombor 108 Tahun 2016 tentang Klasifikasi dan Pengkodifikasi Harta Daerah. Pangkalan data secara langsung disepadukan dengan model tiga dimensi bangunan itu. Dengan melakukan dua perkara ini, akan membina proses pengurusan aset yang disatukan dengan BIM dan boleh digunakan untuk merancang pembangunan aset.

KEYWORDS: BIM; government asset management; TLS 


\section{INTRODUCTION}

Asset management is the science and art to guide wealth management that includes the process of planning asset needs, acquiring, inventorying, conducting legal audits, assessing, operating, maintaining, renewing, or eliminating to transfer assets effectively and efficiently [1]. The purpose of asset management is to simplify the decision-making process so that the assets are managed effectively and efficiently [1]. Asset management has the important role to ensure that asset management and maintenance are undertaken. With asset management, decisions about assets covering procurement, maintenance, and operational and removal costs will be made. Asset management will be required to provide information on the condition of an asset in order for it to answer the projected needs of public sector organizations to perform its functions optimally [2]. Strategic objectives of asset management are implementation of administrative order, the creation of efficiency and effectiveness of asset use, asset security, and the availability of accurate data or information [2].

The problem is that asset management still uses conventional inventory processes [14]. Assets are only coded, recorded, and entered into the asset plan. This conventional asset management has the disadvantages of lacking information on the current state of assets and its location, as well as being difficult to update with current asset information. Therefore, it is necessary to update the asset management process by utilizing existing technology. The research case focuses on assets that are owned by the local government and take place in the Bandung Institute of Technology. The university assets are owned by the Bandung government. At the university's goods assets, there is no textual database and codification system that does not follow the Regulation of the Minister of Home Affairs Number 108 Year 2016 on the Classification and Codification of Regional Property. Asset inventory is only written on paper and put in the room where the asset is, even though some assets, such as chairs and desks, are custom made yet the blueprint or design of these assets is not stored. To solve the above problem, use of Building Information Modelling (BIM) is proposed. BIM is the method for designing and constructing a building that is created in three-dimensional modelling systems and operates in one or more parametric components [3].

The system of BIM is able to interchange data and information about a building in one or more format, with other systems that conform to the agreed formats [3]. Those exchanges are structured by a set of procedures. Thus, BIM consists of a BIM reference model, standard formats for data interchange, and information interchange protocols [3]. The reference model of BIM is based on three-dimensional models of one classroom along with its furniture and electrical equipment assets within the Bandung Institute of Technology. A three-dimensional model of the classroom is captured by a terrestrial laser scanner (TLS). TLS is a device that scans a point cloud of the object.

TLS captures the position of the target object physically, then forms a point cloud in Cartesian coordinates (XYZ) as the result. The point cloud is obtained by measuring emitted and returned the light pulses [6]. The position and value of the target object is determined based on the position of laser scanner. The angle between the scanner head and reflector is also measured to calculate the position during the time of light travel [6]. Figure 1 shows how the laser scanner measures the target's distance. Laser scanners also record the reflected energy from the target surface in the form of an intensity value, which is a function of the target surface characteristics and lighting conditions. Generally, laser 
scanners can define the color of the points that exist in the point cloud based on photo data captured using a camera on the laser scanner. The main advantage of the laser scanner is that it can give a 3D image of an object in detail and accurate. Therefore, laser scanners are widely used in industry Architecture, Engineering, and Construction (AEC) [6].

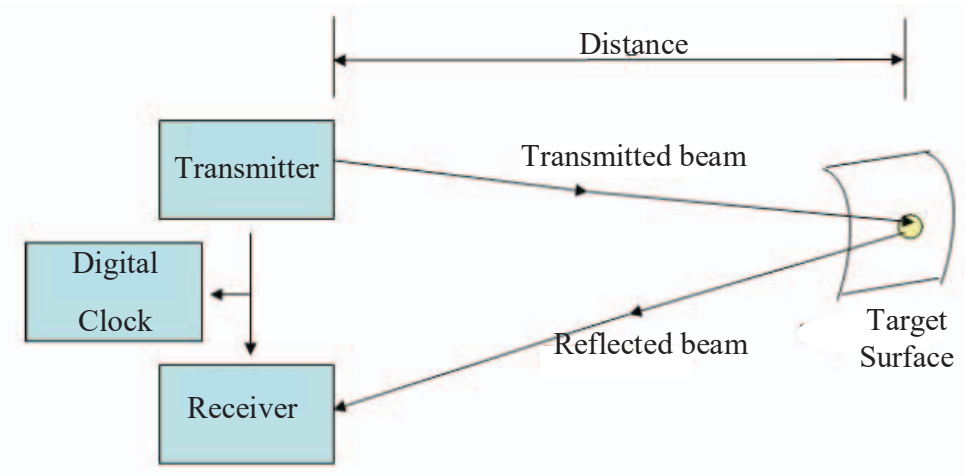

Fig. 1: Distance measurement [7].

Instrument capability and calibration, as well as quality control, affect point cloud data accuracy. Other influences on the accuracy are a function of surrounding conditions such as the reflectivity of the surface, the angle between scanner and target, and the range to target the object [6]. There are several ways to improve measurement accuracy, including:

a. Scan from multiple locations.

b. Shorten the laser scanner's distance to the target.

c. Use dense resolution and slow scanning speed.

d. Use multiple scans of the same object

This research uses Topcon GLS-2000. Figure 2 describes the parts of laser scanner.

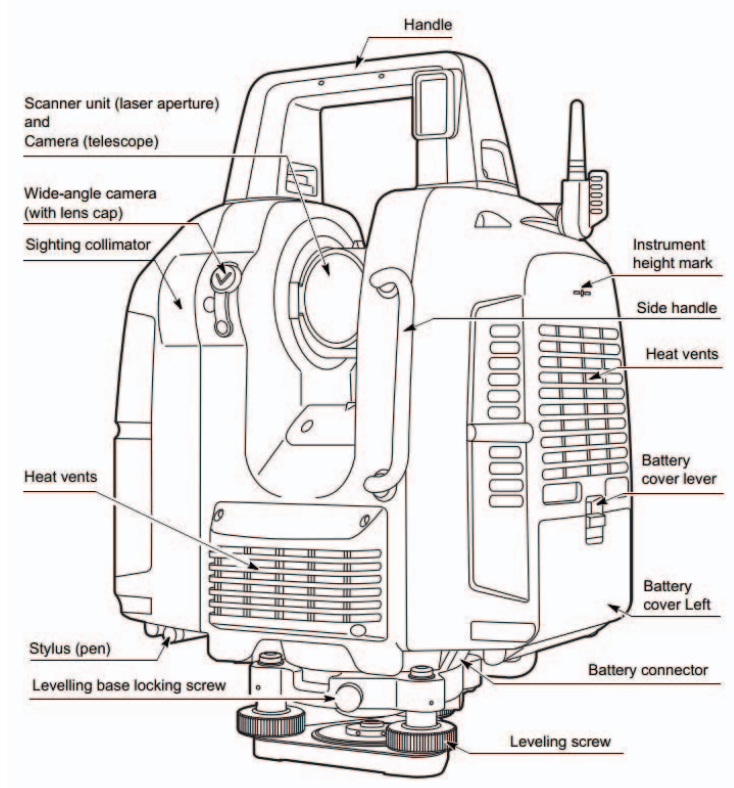

Fig. 2: Topcon GLS-2000 parts [8].

Standard formats for the data exchange is in a form of a textual database which is opened and edited in Microsoft Access, and information of the classroom and textual 
database can be opened concurrently with Autodesk Revit as their protocols. The result of this research is a three-dimensional models of assets that are integrated with a textual database with the code of assets based on the regulation. The significance of this research is to inform the procedure of using TLS, because TLS is still rarely used for modelling assets in three dimensions, even though TLS provides the accuracy of the shape and position of these assets properly. Furthermore, users willing to model an asset in three dimensions may still not know how to integrate this data with a textual database. This study also includes information on integrating the data to textual database. The integration of three-dimensional models from TLS to database results in the initial stage of BIM.

In Indonesia, BIM is hardly used, especially in building asset management. This is due to the lack of human resources that understand and are competent in BIM, as well as the paucity of tools to support BIM. However, in many countries, BIM has begun to be implemented and integrated into the building asset management process. This is due to the emergence of awareness of the needs of three-dimensional and accurate spatial data. Indonesia is a country that is still developing and, in future, BIM technology will begin to be widely used in Indonesia [4].

Nowadays, BIM is becoming a trend. Many of the more sophisticated building owners request the use of BIM that will support systematized checking to control whether the design meets program requests. BIM also demands people with new skills. For example, an architect, which is needed in BIM, will contribute design skill and can also effectively develop well-defined models that can support different assessments for energy or cost/value [5]. An engineer for BIM must be able to extract analysis models needed to carry out structural or energy analysis and propose improvements to the building model design that are especially in demand [5].

BIM is a digital representation of the physical and functional characteristics of the facility within the building. BIM serves as a source of knowledge about in-building facilities that will form a basis for making decisions during the life cycle of the building from the beginning onwards [10].

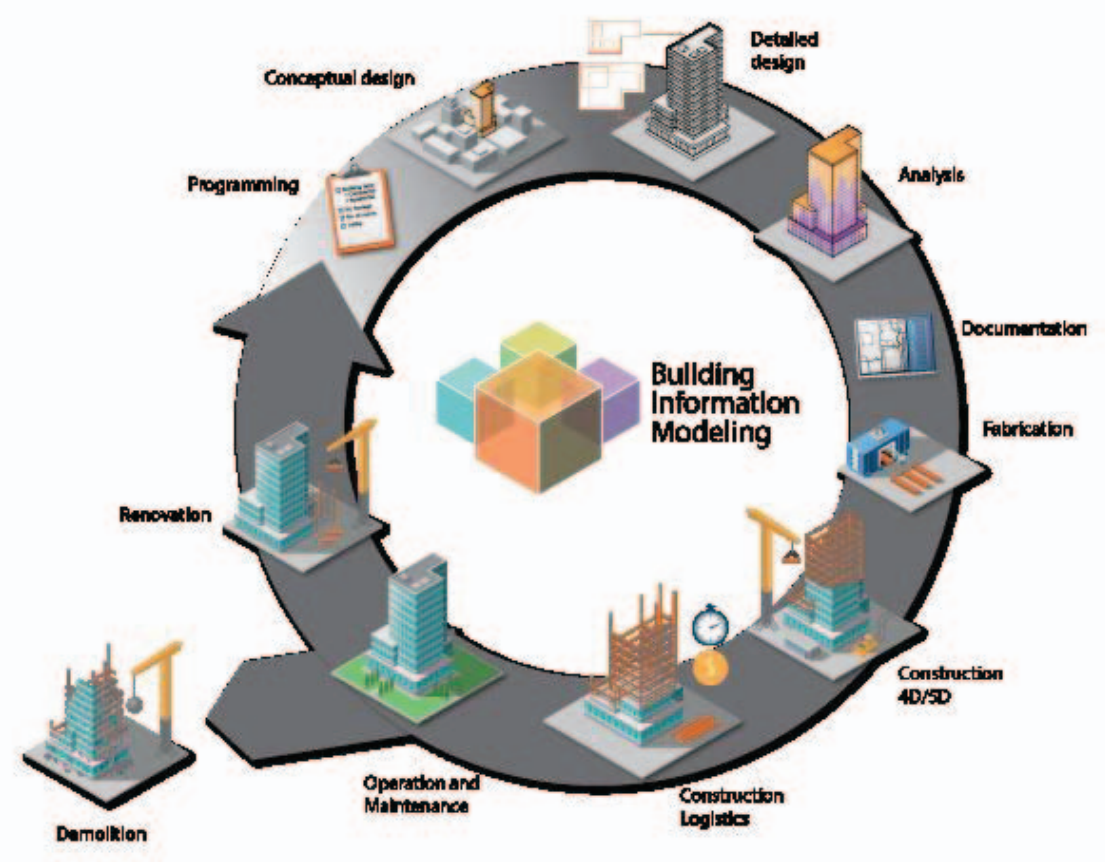

Fig. 3: Life Cycle of BIM [14]. 
BIM changes the way buildings are designed and built. In building construction, simulations are used. From simulations, a BIM user can simulate performance, usage, and costs. It can be concluded that the use of BIM can integrate all aspects of the building, namely in terms of architecture, construction, mechanics, etc. The use of a database in BIM allows designers and contractors to see all development processes from design, construction to building management. BIM also provides plans, sections, elevations, details and schedules that can be modeled in 3D. [11].

The construction process can be made, controlled, and displayed better by using BIM, in addition, there are several benefits of BIM, namely [11]:

a. Three dimensional design visualization to show the reality of the building, thus the building team and client better understand the design

b. Integrated design documents to minimize error

c. The integration of architecture, construction, and mechanics in three-dimensional forms is easier to understand

d. Computerization means that it is also easy to update the building components.

e. Can predict and plan the amount of building material

f. BIM allows to explore sustainable strategies for building design and its surrounding

There are four main steps in BIM. First, identify the value of using BIM in the planning, design, construction, and operational phases. Second, create a system for BIM processing. Third, exchange information from all BIM elements. Finally, make a contract, communication, technology, and quality control procedures that support the implementation of BIM [12]. BIM is also classified into five main objectives. First is gathering information about building, second is generating information about building, third is analyzing to examine elements of the building and determine the viability for the building, fourth is communicating information or design about building elements that can be shared or exchanged, and the fifth is realizing to make or control or develop the building element using the previous information [12].

Some people occasionally mistaken Computer Aided Design (CAD) with BIM. CAD is one component that can form BIM. It's just that there is no integration between data in CAD or separate data. BIM sees buildings not only as data, but as integrated systems, so that the data will be connected to each other and stored in the same location. The difference between CAD and BIM is shown in Fig. 4 [11]. The picture shows no differences between components of CAD and BIM, but the arrows should be noted. On the CAD side, it means all the components are independent and part of CAD Project. On the BIM side, all the components are integrated in BIM.

In the BIM modelling process, there is a stage of accomplishment of the design stage. This phase level is called the Level of Development (LOD). Level of Development (LOD) Specification is a standard that can be used by someone engaged in industry related to the building with the aim of explaining the stages of BIM development in the design and construction process, so that users can define their project will meet what level of LOD. Model authors can delineate what their models can be depended on for and let users or customers recognize the ability and the limitations of the models, based on LOD. Thus LOD is not defined by design phases, but vice versa, the design phase is defined by LOD [9]. This research used LOD 300, which means the model element is depicted graphically in the model as a system, object, or specific assembly in terms of quantity, size, shape, location, and orientation. Non graphic information is included in the model elements. The quantity, size, shape, location, and orientation of the designed elements can be measured directly from the model without referring to non-model information such as notes or 
dialing dimensions. The project's origin is defined and the element lies accurately related to the project's origin. LOD 300 error tolerance is $6 \mathrm{~mm}$ [9].

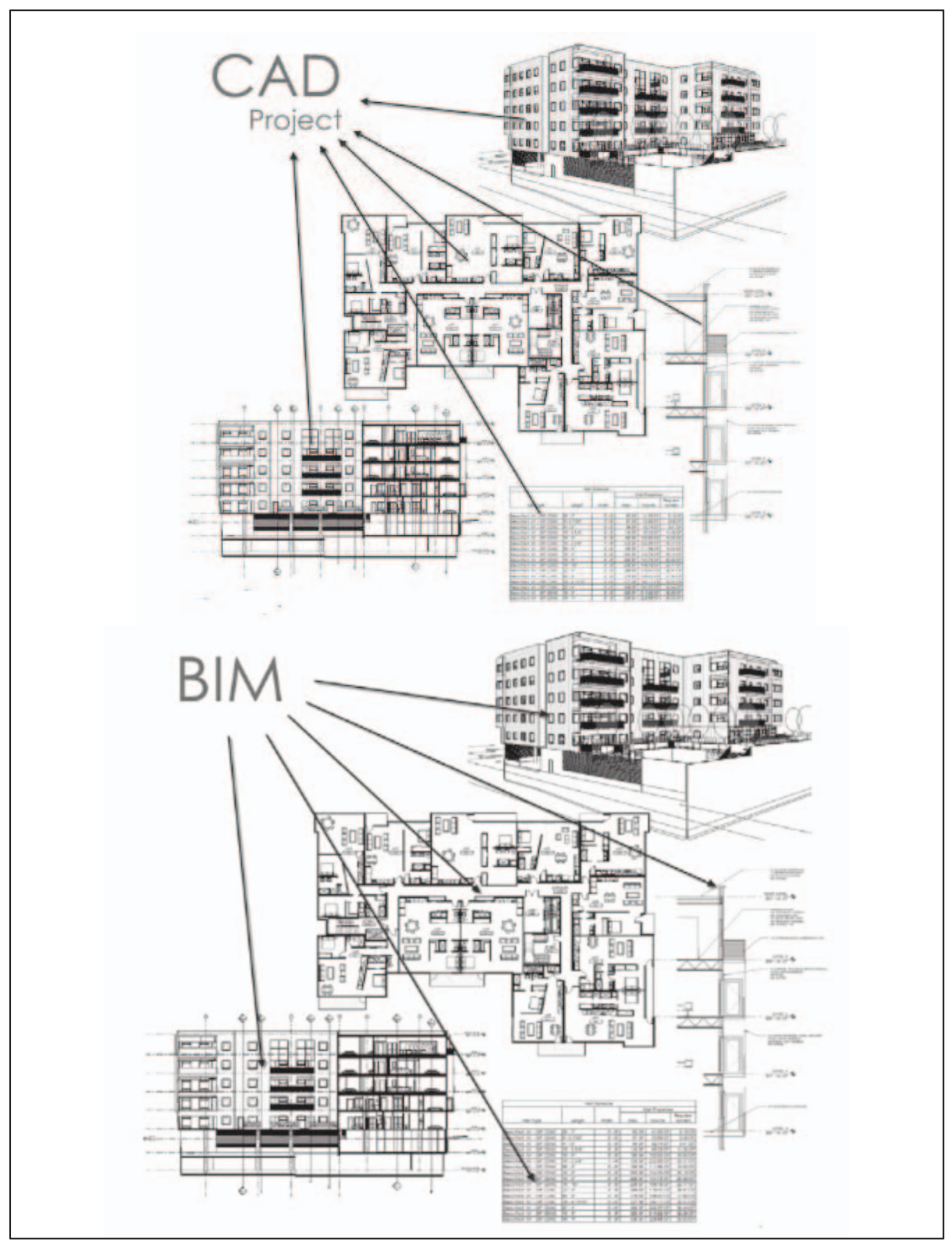

Fig. 4: The Difference between CAD and BIM [11]. 


\section{MATERIALS AND METHOD}

This section explains literature review about acquisition data and methodology. This section shows the material that is used in this research and the method to process the material. An algorithm of methodology is shown in Fig. 5.

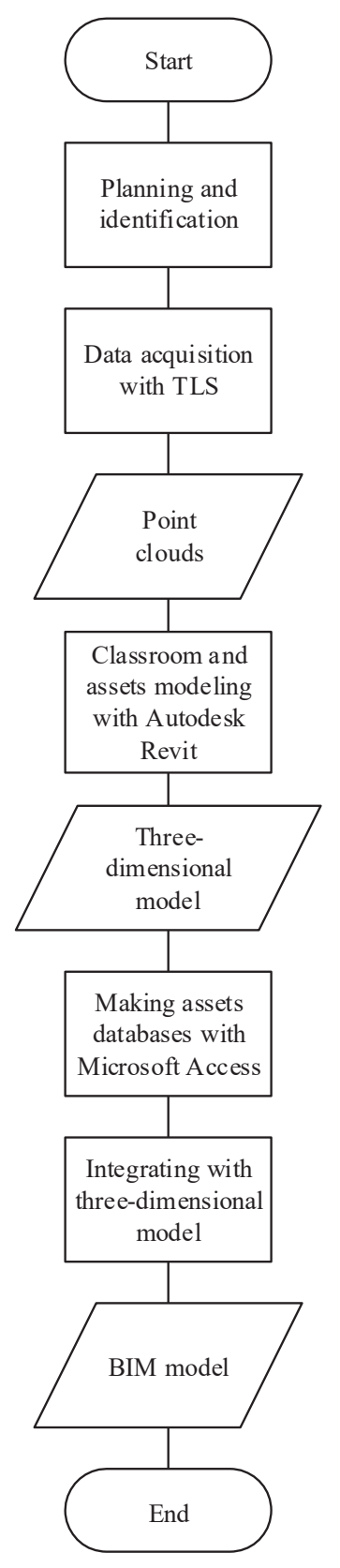

Fig. 5: Methodology.

\subsection{Data Acquisition with TLS}

In this step, the position of TLS must be planned, because each point cloud of room and assets must be overlapped. Once planned, the tripod is set in the planned position and turned on, as shown in Figure 6. Next, TLS will do its internal calibration automatically. After that, levelling the TLS must be done, and an auto tilt feature is turned on to correct tilt of data after scanning automatically. The coverage of data, resolution, and speed of 
TLS when data acquisition will be started are all set by the user. Then, storage is verified to be certain that there is room for the acquisition data to be saved.

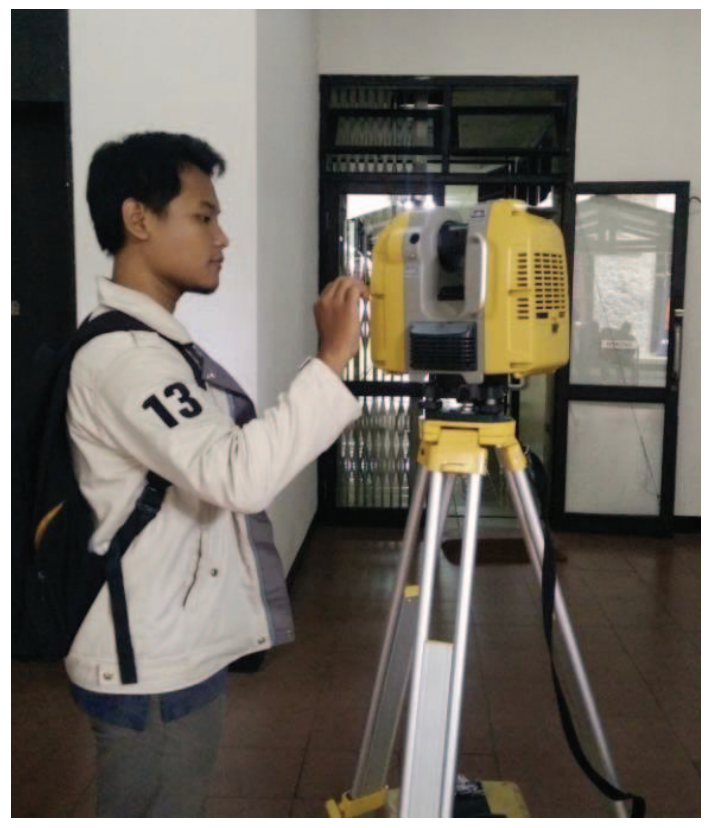

Fig. 6: Setting the TLS.

After setting the TLS, the "Start Scan" button on the TLS is pressed. TLS will start taking a panoramic photo (360 degrees) to give the color of the point cloud. After taking the photo, TLS will rotate 360 degrees and start beaming the laser to get object points. After a completed scan, data will be saved on the SD card inside the TLS. After saving data, the TLS remains on and is repositioned to the next planned position. A single data acquisition cycle is five minutes with a resolution of $12.5 \mathrm{~mm}$ and low power speed mode. For this research, data acquisition took two days, based on a plan and get 27 data scans. Data was then moved from the TLS to a computer with Topcon Scan Master software and saved as .e57 extension.

\subsection{Point Cloud Cleaning}

The raw scan data contains a lot of noise and unnecessary points, thus cleaning needs to be done. Figure 7 shows the procedure and Fig. 8 shows the raw scan data that contains noise.

Open scan data from TLS
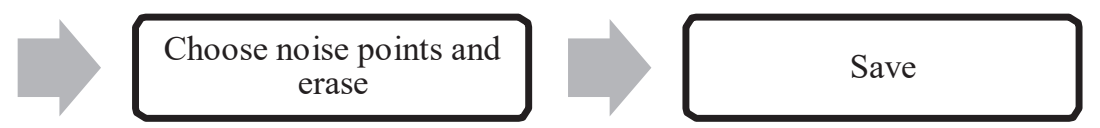

Fig. 7: Point cloud cleaning procedure.

The one-by-one point cloud is manually cleaned using Maptek i-Site software. This cleaning process aims to prepare the registration process point cloud and provide good results. In addition, by eliminating noise and unnecessary points, the size of the point cloud file will decrease. Objects such as humans, trees outside buildings, vehicles, and objects outside buildings are noise and should be removed. The result of this cleaning process is a clean point cloud free of noise [14]. Figure 9 shows the point cloud from Fig. 8 that has been cleaned of noise. 


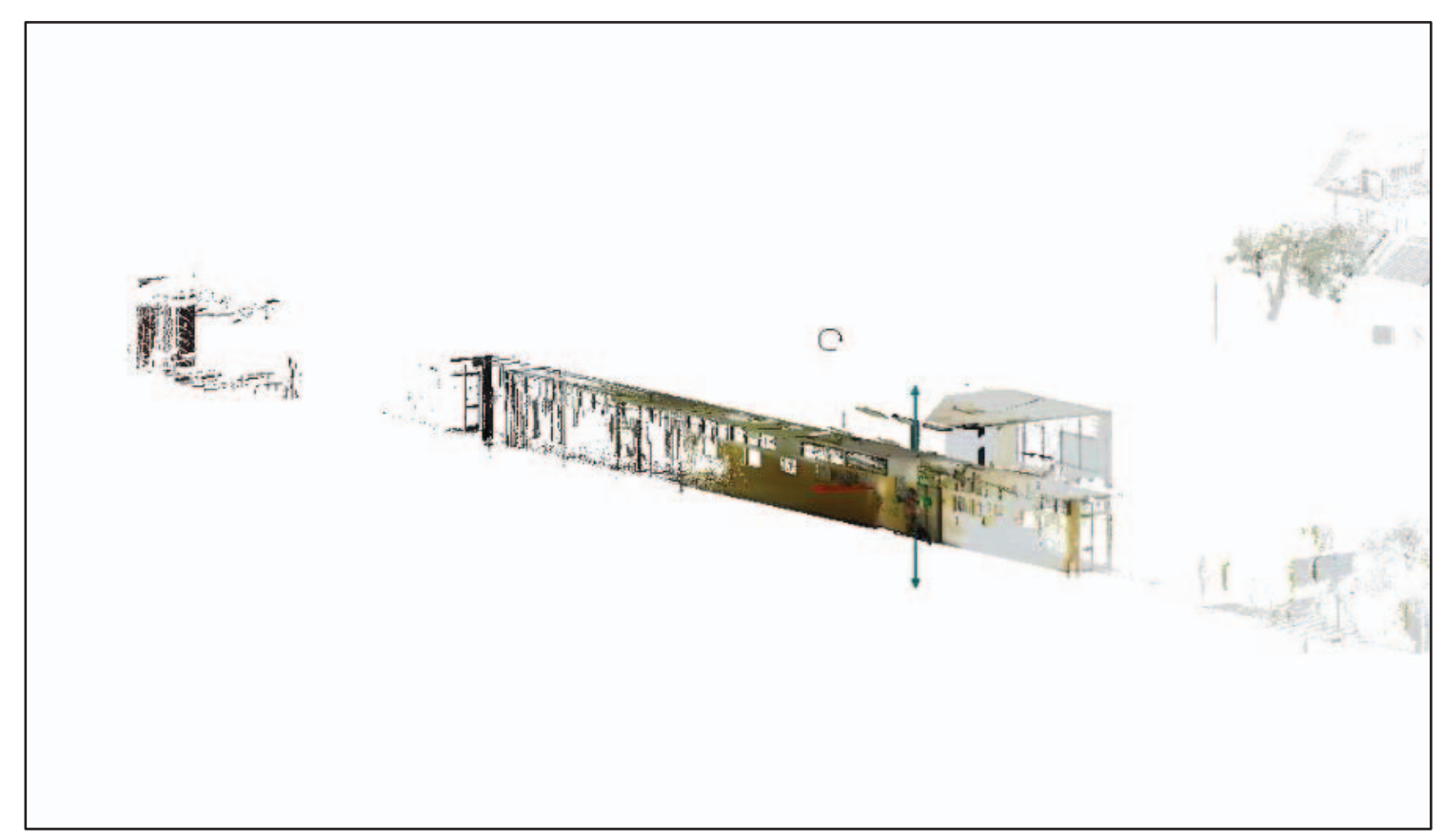

Fig. 8: Raw scan data with noise.

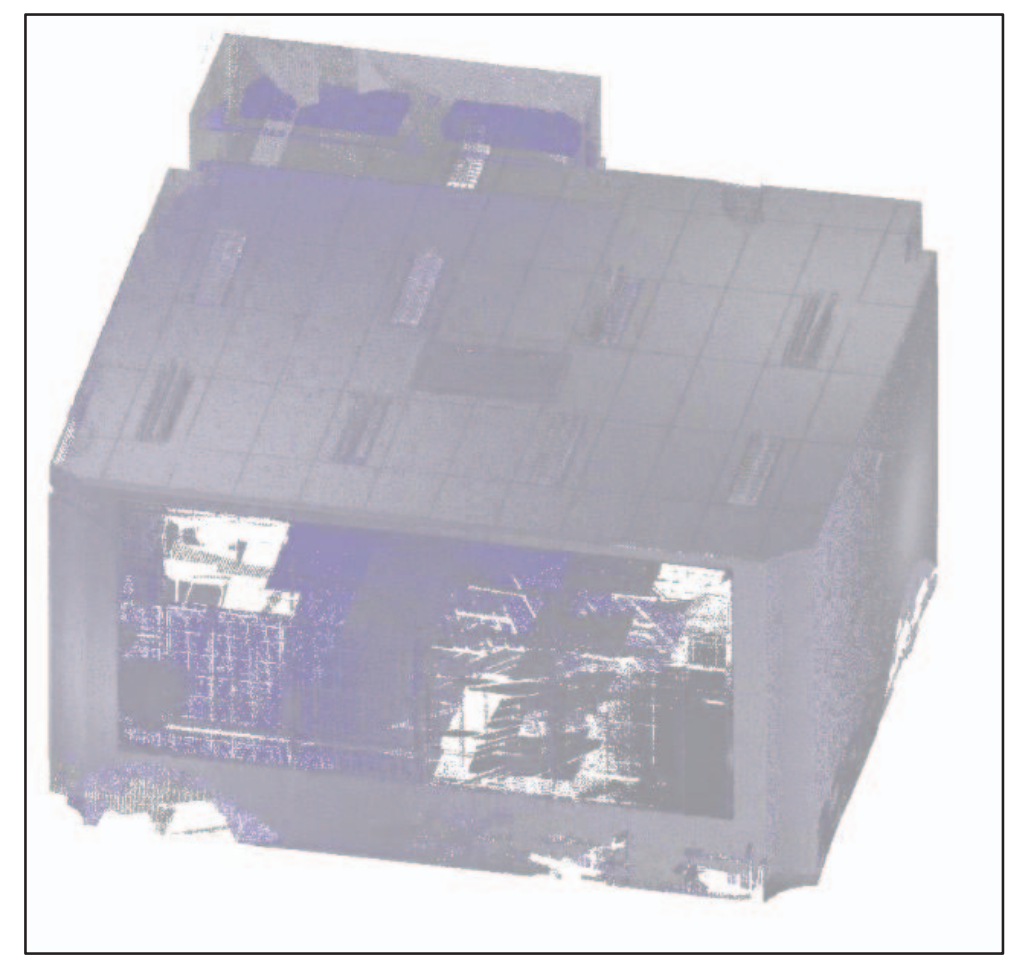

Fig. 9: Point cloud without noise.

\subsection{Point Cloud Registration}

The point clouds that have been cleaned from noise are combined into one through the registration process, the procedure for this is shown in Fig. 10. Registration is the process of aligning some point clouds so that they are in the right position against each other. 


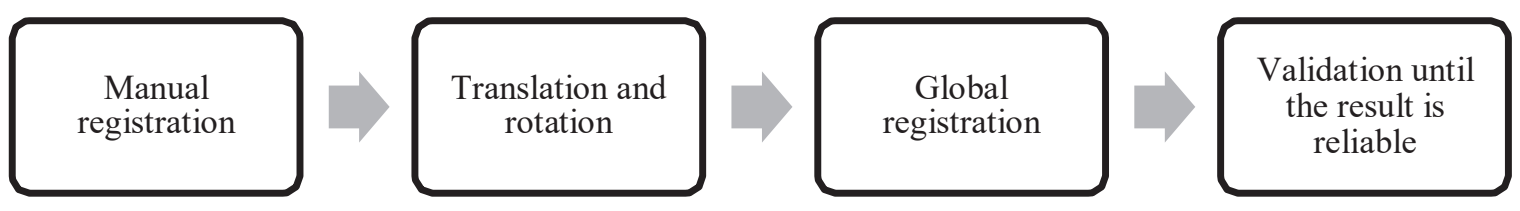

Fig. 10: Point cloud registration procedure.

The point cloud data can be registered to a reference point cloud by translating and rotating manually to the same point, then continuing with global registration to fix the position [13]. Registration is manually done by doing the translation and rotation to set the position of the two-point cloud to coincide at the same point. Manual registration may be referred to as coarse registration. Global registration is also a process of translation and rotation. Global registration uses an Iterative Closest Point (ICP) algorithm. Global registration can be referred to as fine registration [14]. Figure 11 shows the process of global registration.

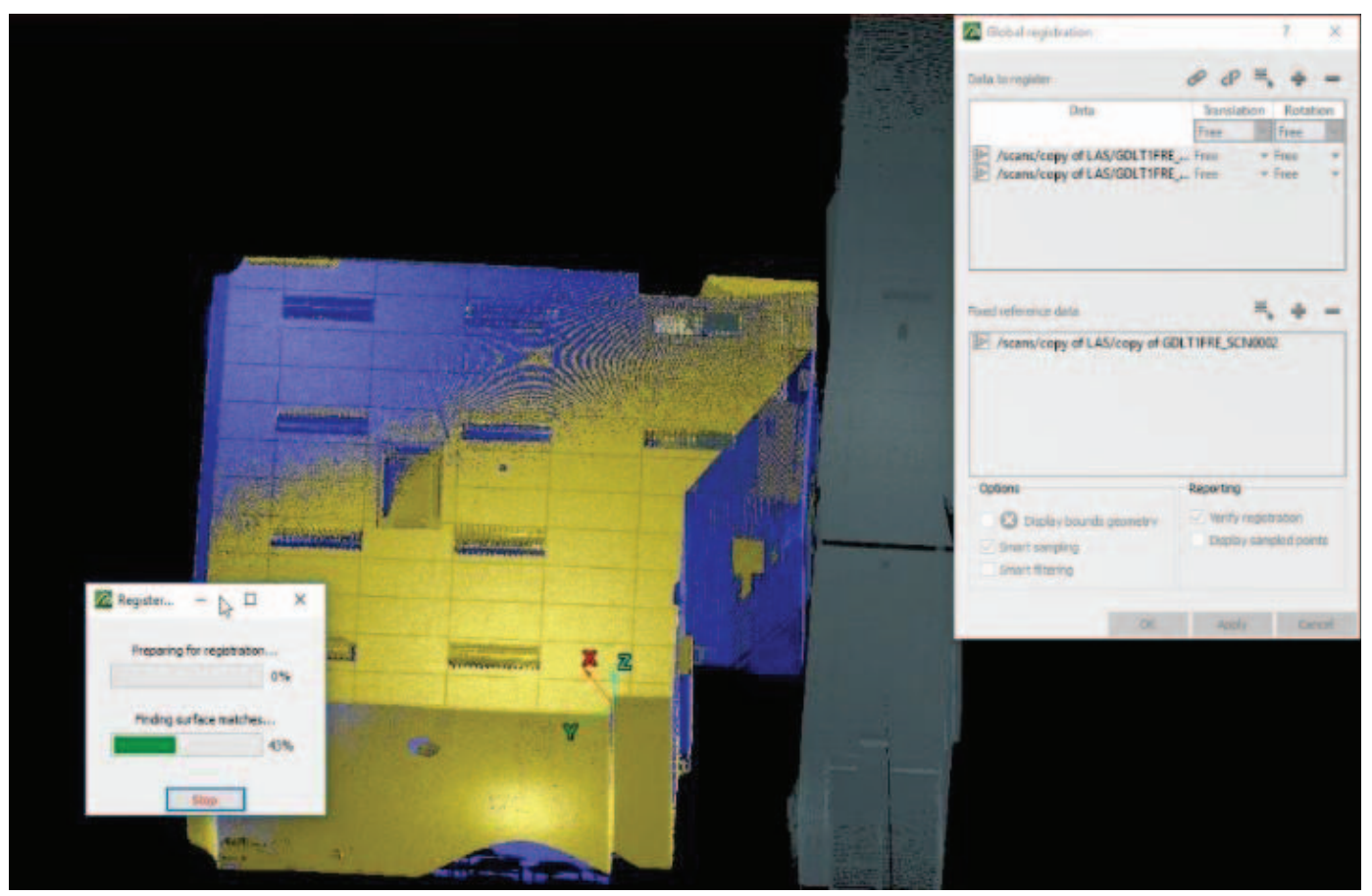

Fig. 11: Global registration.

After the registration process is complete, then the validation is done to know the quality of the registration result. Validation is divided into two kinds, namely, qualitative and quantitative. Validation is qualitatively done by observing whether the point cloud is integrated into the correct position (the same object), if it is not correct, the registration process is repeated. Quantitative validation is done by examining the RMSE (Root Mean Square Error) distance and the number of points in pairs. The distance RMSE value signifies the accuracy of the registration process. The smaller the RMSE value, the better the registration results. The distance of RMSE describes the mean distance between the sample points that were used in the registration process. To minimize the RMSE value, the global registration process is done with several iterations. The final value of RMSE depends on several factors such as the amount of scan data, scan resolution, and the amount of overlap. The value of RMSE will vary with each set of scan data and there is no 
minimum value to be able to say that the scan data has been registered finely [13]. Table 1 shows the validation of global registration.

Table 1: Global registration validation result

\begin{tabular}{|c|c|c|c|c|c|c|c|}
\hline & Data & Warning & Error & $\begin{array}{l}\text { Matched point } \\
\text { pair count }\end{array}$ & Warning & Error & $\begin{array}{l}\text { Registered } \\
\text { RMS separation }\end{array}$ \\
\hline 1 & F GLT1FRE_SCN0003 & 100 & 50 & 614 & $0,100 \mathrm{~m}$ & $0,200 \mathrm{~m}$ & $0,003 \mathrm{~m}$ \\
\hline 2 & D GDLT1FRE_SCNOOO4 & 100 & 50 & 586 & $0,100 \mathrm{~m}$ & $0.200 \mathrm{~m}$ & $0.003 \mathrm{~m}$ \\
\hline 3 & copy of GDLT1FRE SCNO002 & 100 & 50 & 406 & $0,100 \mathrm{~m}$ & $0,200 \mathrm{~m}$ & $0,003 \mathrm{~m}$ \\
\hline
\end{tabular}

\subsection{Point Cloud Indexing}

Registered cloud points need to be converted to an RCS format to be opened in AutoCAD Revit software. Using Autodesk Recap software, the registered cloud points are converted to RCS format through the indexing process. Point clouds that have been formatted by RCS can then be used as a reference for making a BIM model in Autodesk Revit [14]. Figure 12 shows the procedure of indexing.

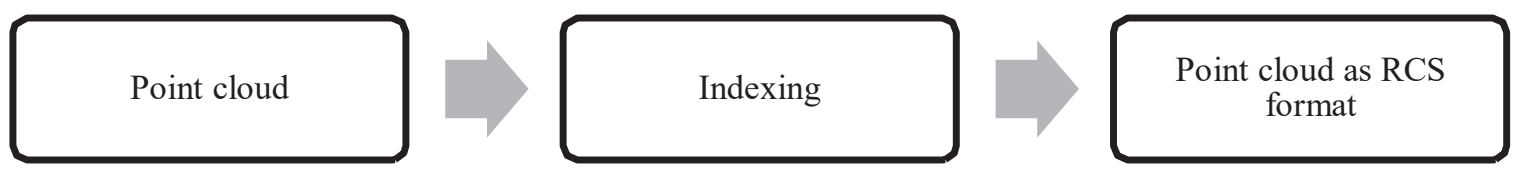

Fig. 12: Point cloud indexing procedure.

\subsection{Point Cloud Extraction}

Extraction is the step of separating the asset points from the overall point cloud. The extraction process produces a point cloud of assets and a point cloud of the classroom. This process is done using Autodesk Recap software. The procedure is shown in Fig. 13.

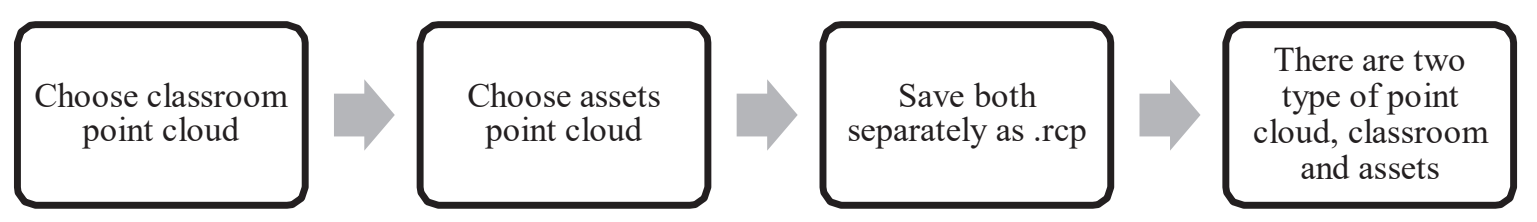

Fig. 13: Point cloud extraction procedure.

Figure 14 shows the process of point cloud extraction. The point cloud of the classroom is used for reference in the making of room models and the asset point cloud is a reference for making the asset model. The extracted room and asset point clouds are stored in separate files. The next process is to create a BIM model using Autodesk Revit [14].

\subsection{Creating the BIM Model}

The BIM modelling is done using Autodesk Revit. The BIM models are of two types, the model of the classroom and the model of assets. The classroom model is made as a Revit project type, while the asset model is made as a Revit family type. Revit project is the master file that will be the place to store the asset model. In this study, the room that made the model is classroom 3010. The procedure of creating the BIM model is shown in Fig. 15. 


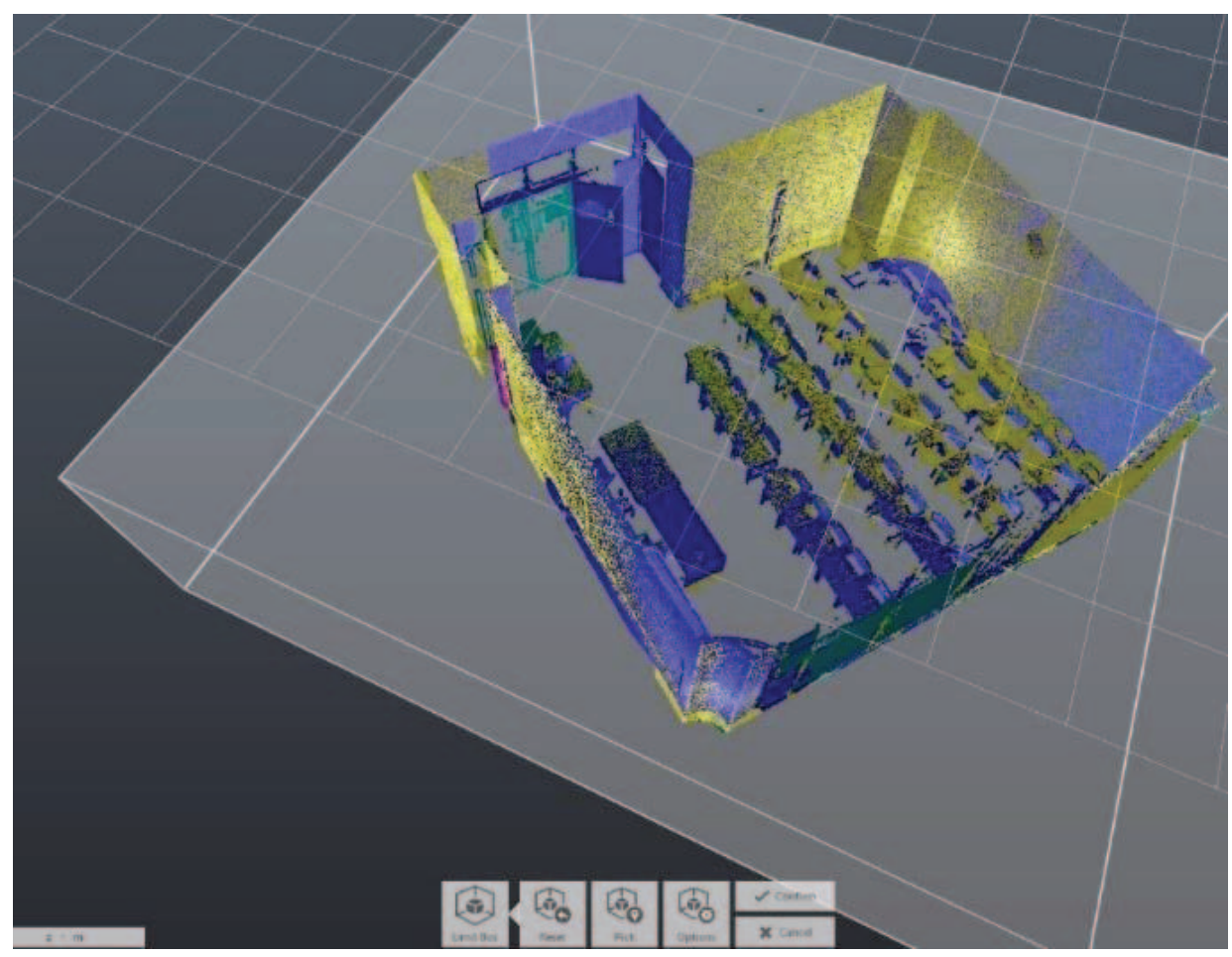

Fig. 14: Point cloud extraction.

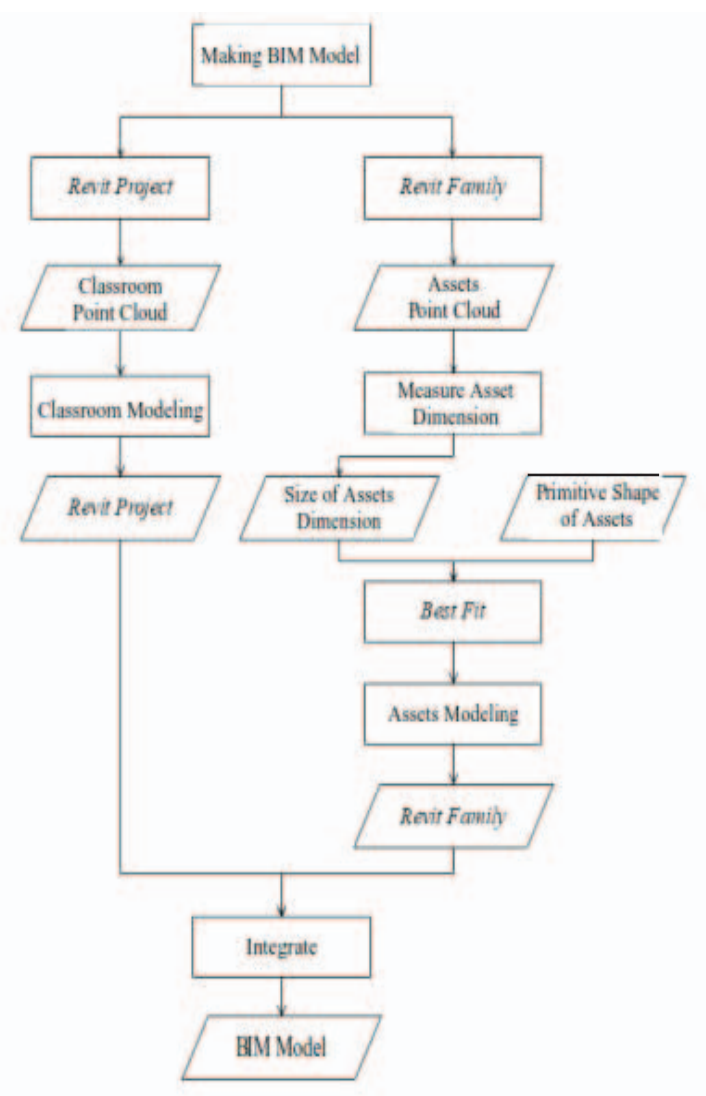

Fig. 15: Creating BIM model procedure.

In the process of modelling the room, the extracted space cloud point is inserted into the Revit project to be used as a mould. The size of the model will follow the size of the 
room's cloud point and is the actual size in the real world [14]. Figure 16 shows the process of making classroom and assets models with the point cloud as their mould.

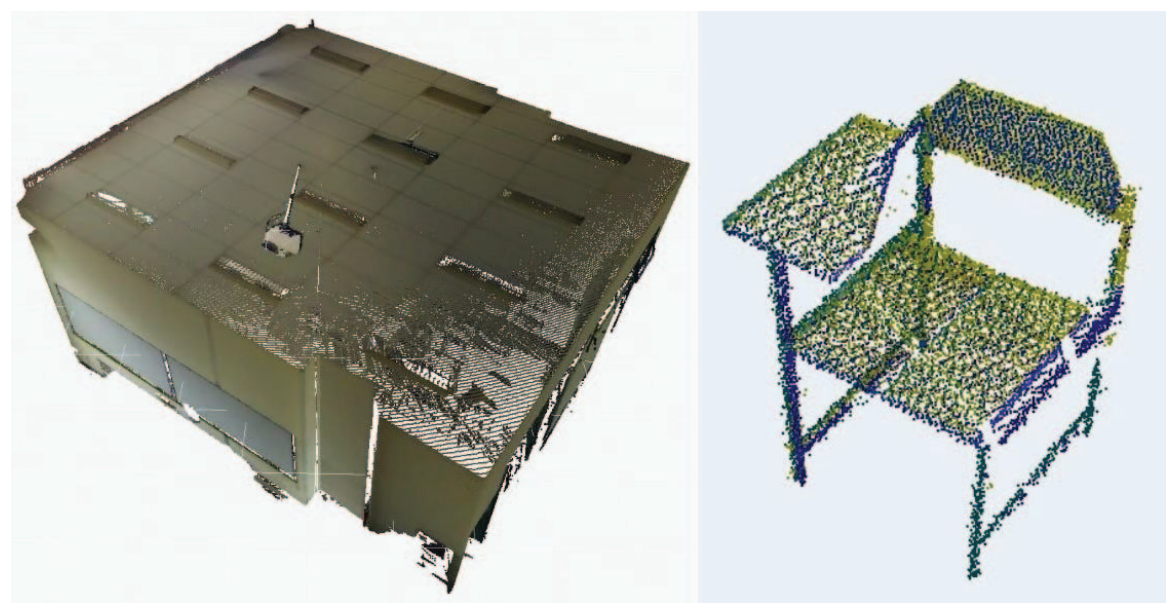

Fig. 16: Classroom and assets modelling.

The asset modelling process is slightly different from classroom modelling because the point cloud cannot be imported into the Revit family. The extracted asset point cloud is measured in dimensions (length, width, height) using Autodesk Recap. For example, Figure 17 shows the measurement of the dimensions of a door. Assets are modelled using templates that are already available in the Revit library. The asset template is resized and shaped according to the asset point cloud. This will create an asset model similar to the actual form of the asset in real world. Similar assets require only a single model that can be copied as many times as the asset appears in the real world. The quality of the resulting model is highly dependent on the ability of the user. The completed asset model is then entered into the Revit project model that has been created [14].

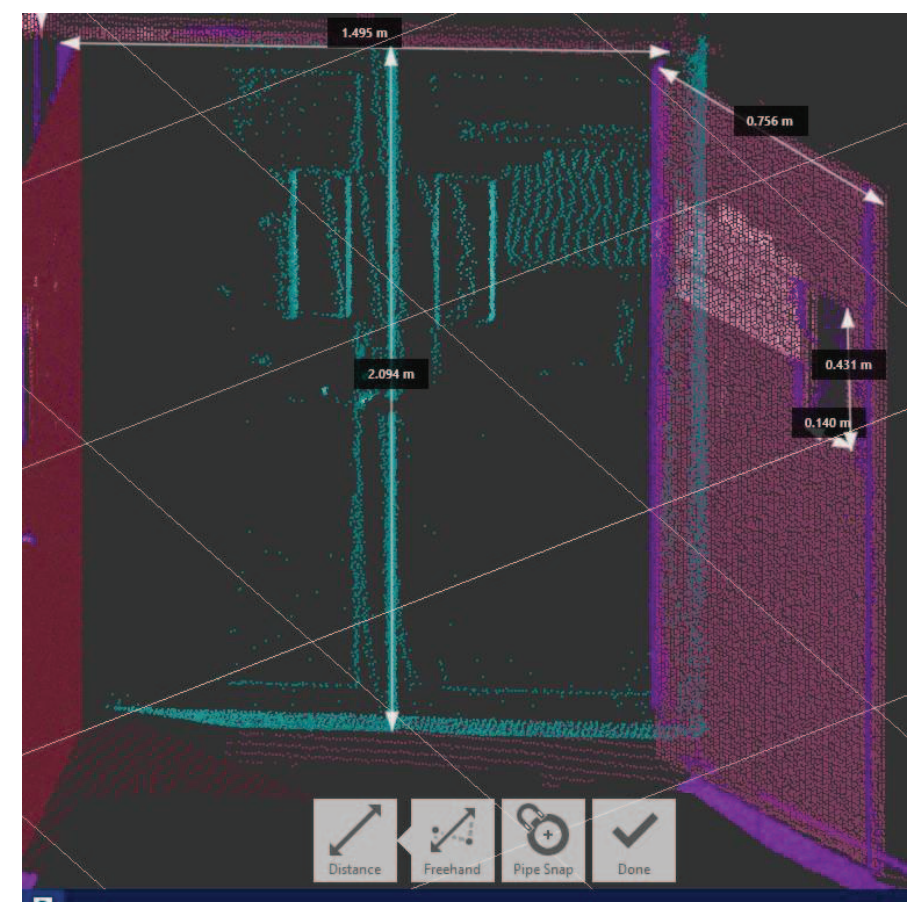

Fig. 17: Door dimensions. 


\subsection{Assets Database Integration}

After the BIM modelling process is finished, the next step is to create an asset database. The contents of the asset database are based on the needs of the user. Each asset model that has been created contains editable descriptions with added parameters to the Revit family. To be able to create database files or connect with database files, the Revit DB-Link add-in and database programs are needed. Figure 18 shows the procedure of assets database integration.

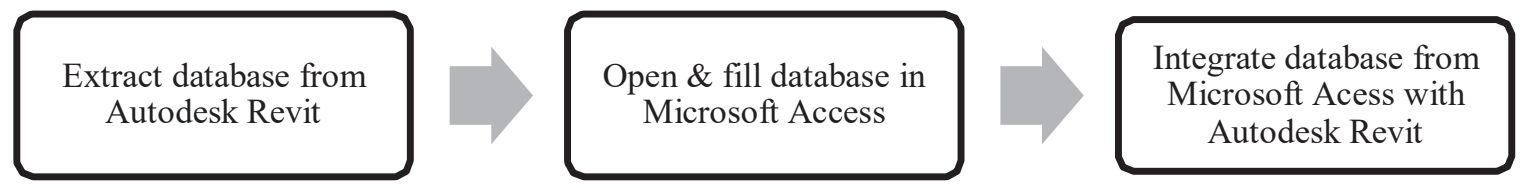

Fig. 18: Assets database integration procedure.

In this research, Microsoft Access is used as database software. By using Revit DBLink it is possible to export a Revit project in a database file, make data changes, and import it back into Revit project. The dialog box is shown in Fig. 18.

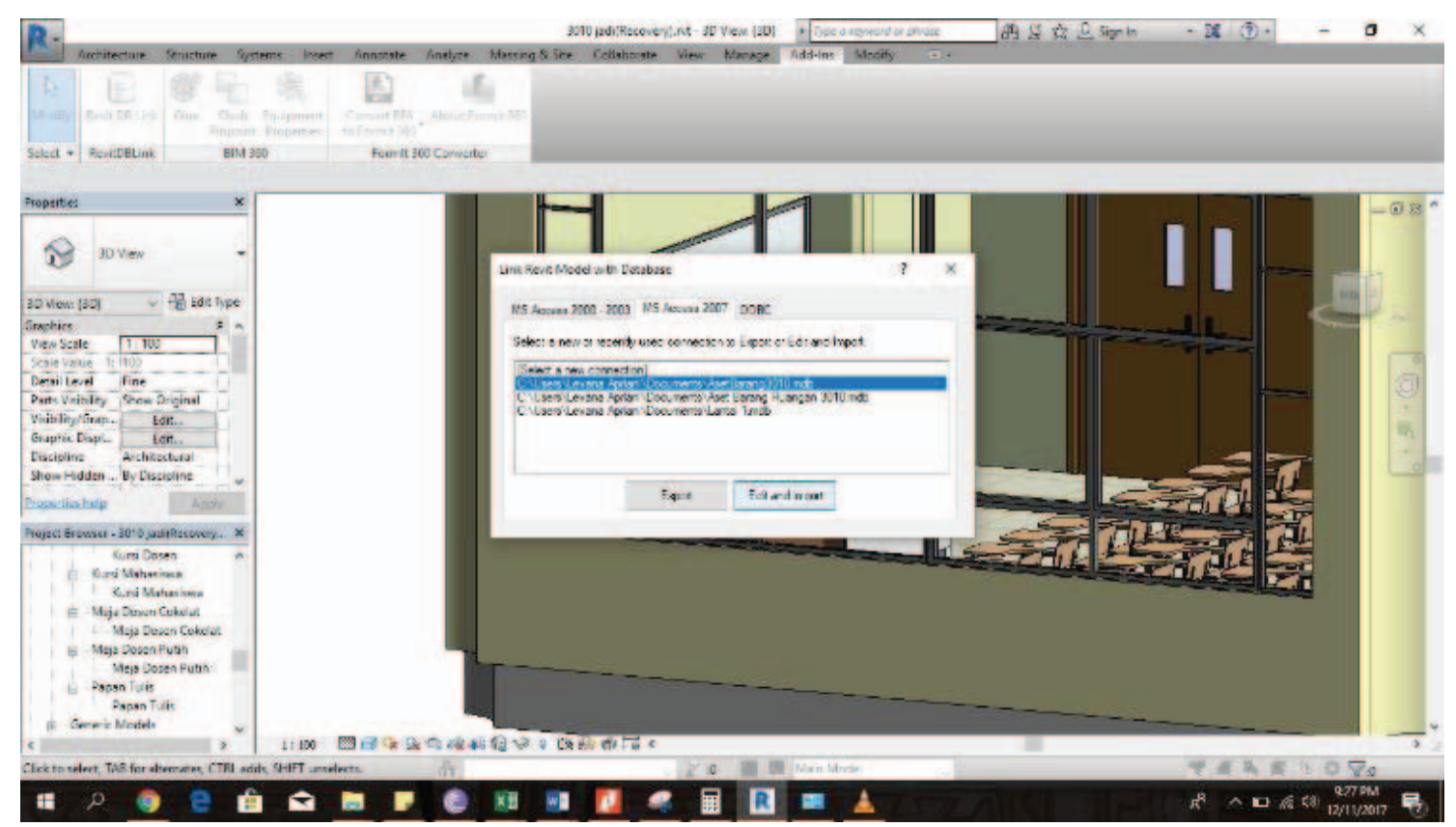

Fig. 19: Export and import database of BIM.

The Revit project that was exported will create a database file with .mdb format. The database file can be opened and edited with Microsoft Access. The database file contains information that is attached to the BIM model. New information can be inserted into the Revit project by changing or adding the information to the database file, then importing the database file into Revit project using Revit DB-Link.

\section{RESULTS AND DISCUSSION}

\subsection{Results}

The BIM model has been divided into: 
a. Model room consists of walls, floors, and ceilings. Figure 20 shows the result of making a room model. The room model has the shape and size in accordance with the actual room in the real world because the room model is made based on the data point cloud of the room itself.

b. The assets model is created from Revit family templates that are resized and shaped according to asset point cloud data. This could be a model that is being built real circumstances. Figure 21 is an example of a successful asset model.

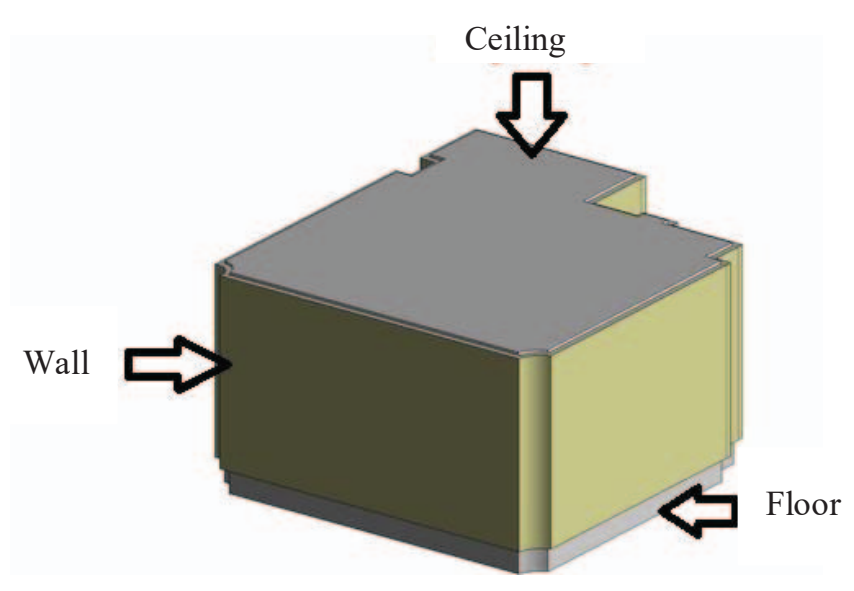

Fig. 20: The result of making a classroom model with Autodesk Revit using Revit Project.

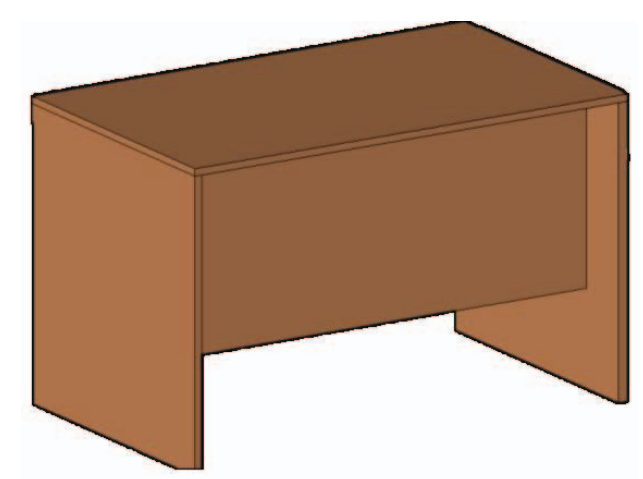

Fig. 21: The result of making a desk model with Autodesk Revit using Revit Family template of table.

The accuracy of asset modelling is the result of the resolution of the laser scanners used. The higher the resolution used, the easier and more accurate the resulting model. This study used a resolution of $12.5 \mathrm{~mm}$ (the overall size of $12.5 \mathrm{~mm}$ on each side of the model). In addition, objects smaller than twice the resolution $(25 \mathrm{~mm})$ cannot be modeled because the shape is not recognizable. For example, an Electronic Total Station (ETS) was attempted to be scanned with TLS. Because ETS has so many components that have a size under $5 \mathrm{~cm}$ or the resolution of TLS, then the result is hard to be identified. Figure 22 is an example of an unidentifiable ETS point cloud. 


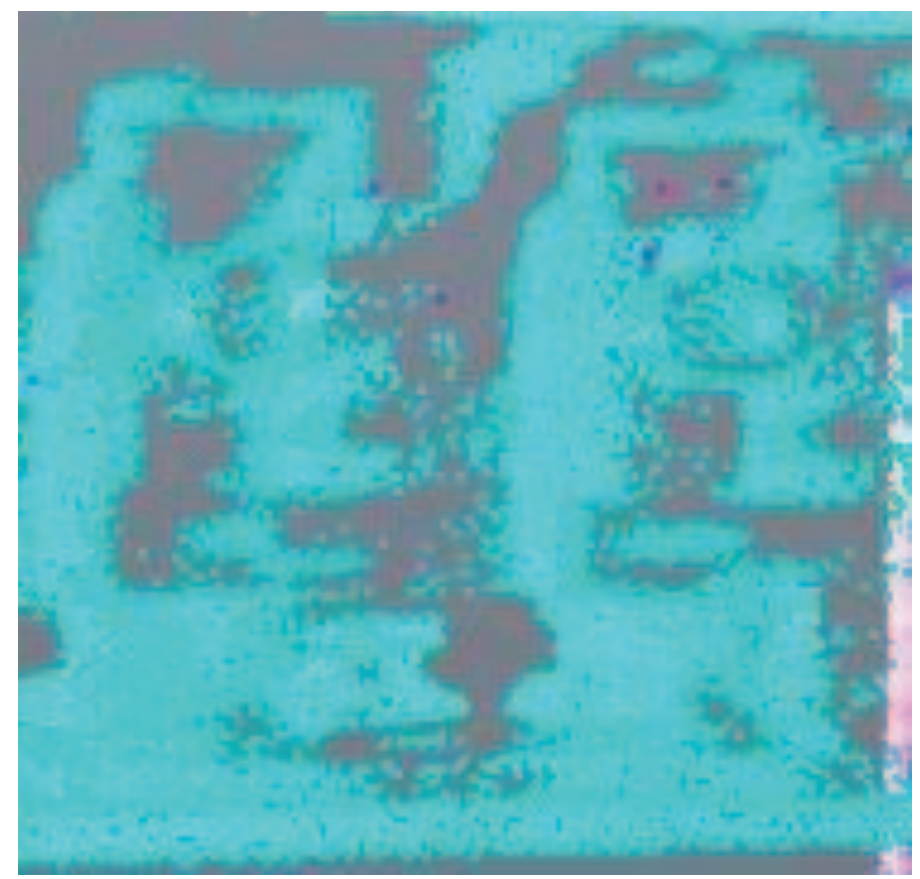

Fig. 22: ETS as unidentified scanned object.

When it comes to complex shape and many detailed objects, a tighter resolution of laser scanners should be used to form an ETS is with a resolution of $3 \mathrm{~mm}$. All Revit family that has been made are put in the proper position with the help of the point cloud. The process of integrating the Revit project (classroom) with the Revit family (assets, such as desk, chair, whiteboards, etc.), based on the Life Cycle of BIM, is the "Detailed Design" stage. Figure 23 is a room model that has been completed with a variety of families [14] and Fig. 24 is room in the real world.

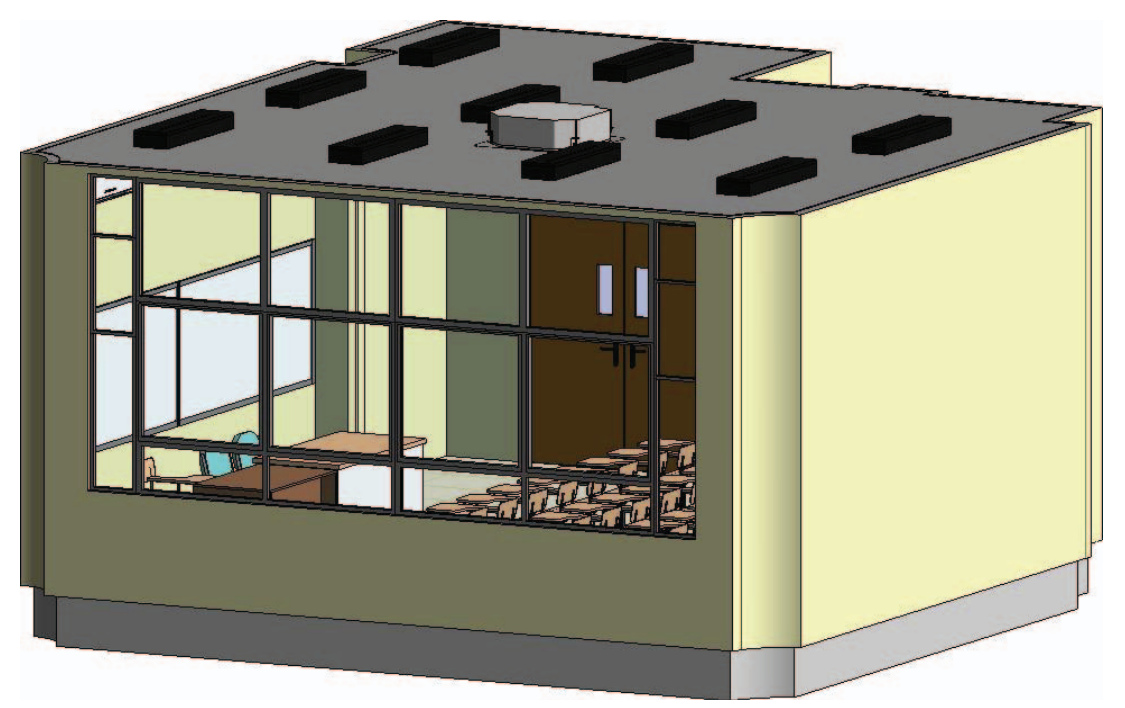

Fig. 23: The final BIM model.

The model and actual classroom have a fairly high level of similarity. TLS takes a position based on the point cloud taken. It is just that in reality, the shape of the chair has changed, because the photo was taken when the study was completed and the administrative staff had changed the seat model, but the structure of the room was similar. 

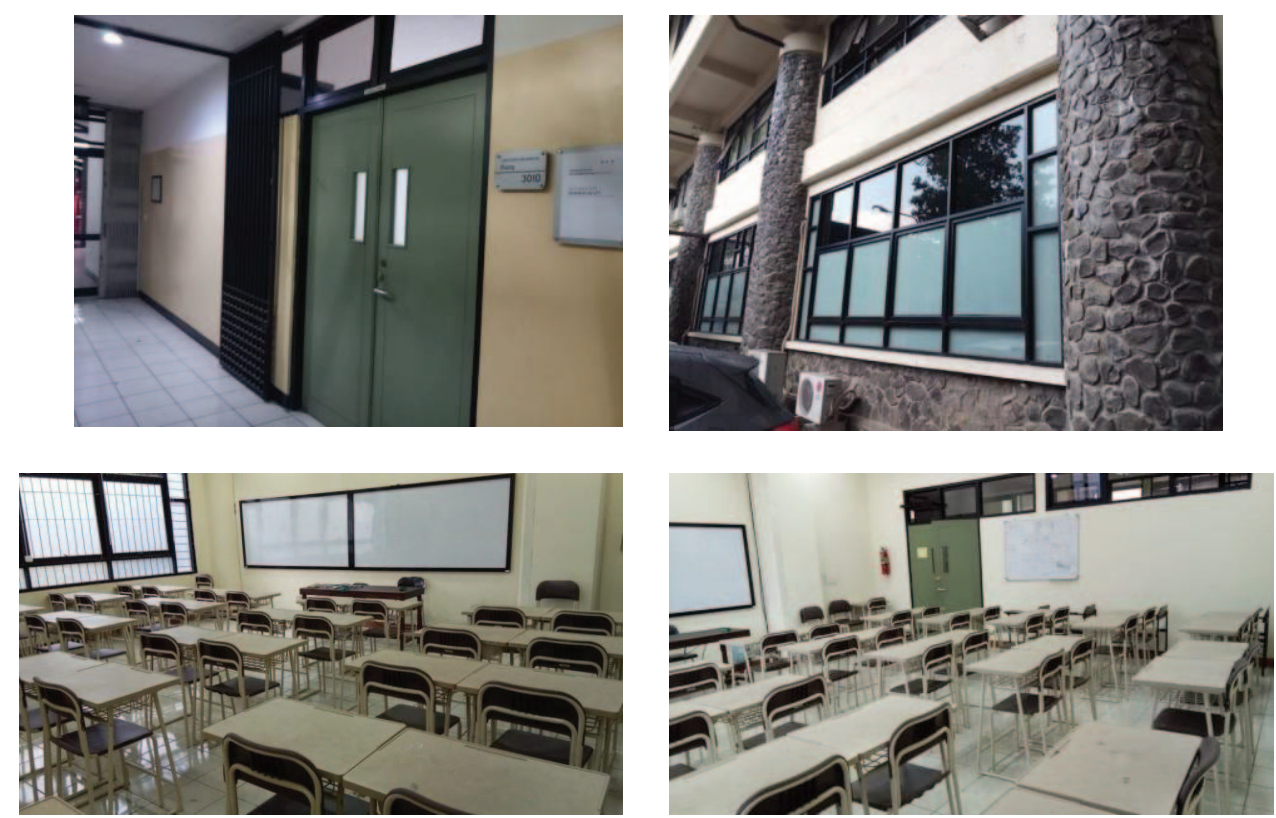

Fig. 24: Classroom and assets in the real world.

\subsection{Discussion}

The final BIM model can be used for various purposes. This study is used for inventory of government assets in the form of furniture and electronic appliances. Inventory data included are the date of inventory, asset name, location code, asset code, brand / type, year of purchasing, seller, procedure to get asset, price, and condition. The addition of these attributes is done on Autodesk Revit by adding parameters. Adding a new parameter is shown in Fig. 25.

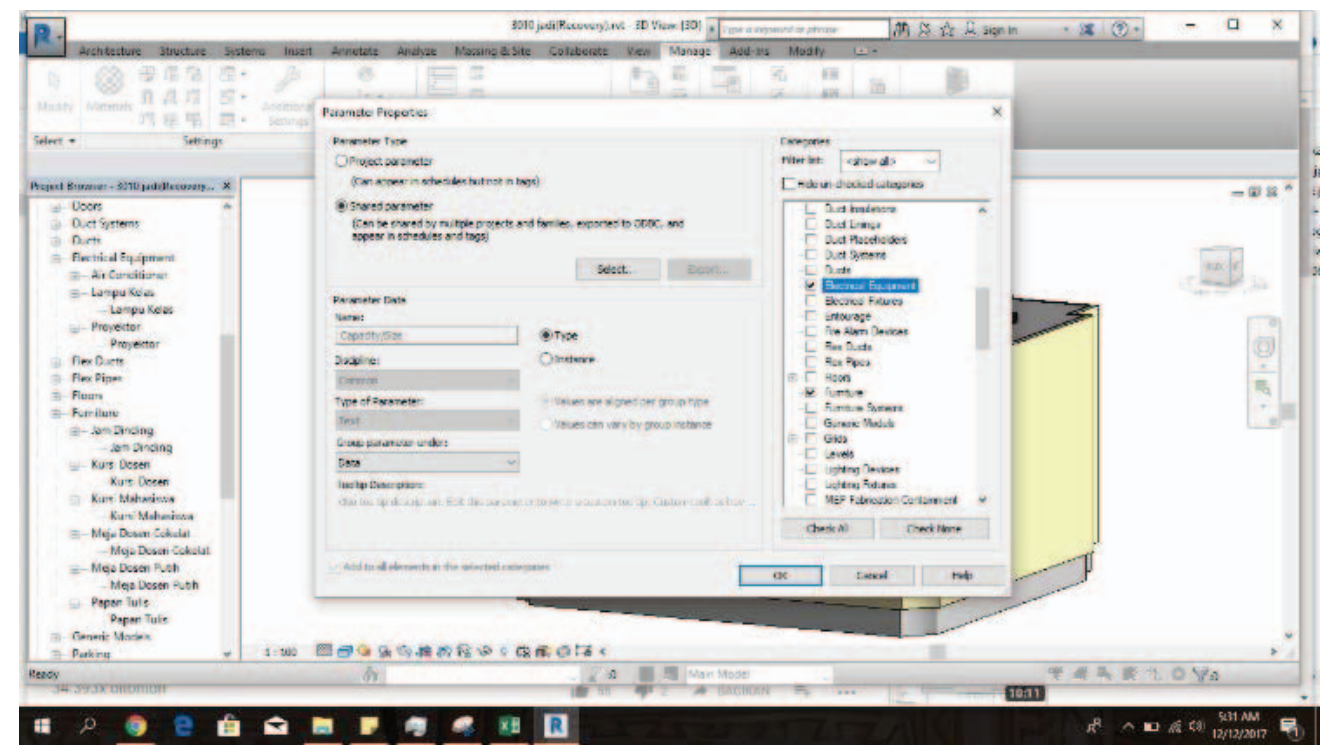

Fig. 25: Adding a new parameter.

After the addition of parameters, the next step is to enter data in Microsoft Access by exporting BIM graphics data. The result will be a database that has been integrated with a 
BIM classroom model. In Microsoft Access, data editing is done by adding elements to the new attribute, one of which is to add the location code and assets. Location and asset codes refer to Regulation of the Minister of the Home Affairs Number 108 Year 2016 on the Classification and Codification of Regional Property and its attachment. For example, the location code has the format "12.32.73.08.01.15.99" and the asset code is "1.3.2.05.02.06.069.0001" as described in Table 2 and Table 3.

Table 2: Location Code for Asset

\begin{tabular}{|c|c|c|}
\hline No. & Code & Explanation \\
\hline 1 & 12 & Owned by local government \\
\hline 2 & 32 & Province code for West Java \\
\hline 3 & 73 & City code for Bandung \\
\hline 4 & 08 & Code for Education and Culture Sector \\
\hline 5 & 01 & Code for Local Education Board \\
\hline 6 & 15 & Year of purchase \\
\hline 7 & 99 & $\begin{array}{l}\text { Code for Bandung Institute of Technology } \\
\text { (Simulation) }\end{array}$ \\
\hline
\end{tabular}

Table 3: Asset Code for Asset

\begin{tabular}{ccl}
\hline No. & Code & \multicolumn{1}{c}{ Explanation } \\
\hline 1 & 1 & Code for asset \\
2 & 3 & Code for fixed asset \\
3 & 2 & Code for equipment and machine \\
4 & 05 & Code for office and home equipment \\
5 & 02 & Code for home equipment \\
6 & 06 & Code for another home equipment \\
7 & 069 & Code for lamp \\
8 & 0001 & Number of lamp \\
\hline
\end{tabular}

The use of Autodesk Revit aims to follow the concept of BIM, which is integrated data. When using other software there is the possibility of data scattering and not having protocol to exchange data. Autodesk Revit can also do cost calculation, scheduling, until further development. In this manner, all aspects of a building can be integrated well and easily accessed according to user needs. The textual database is shown in Figs. 26 and 27.

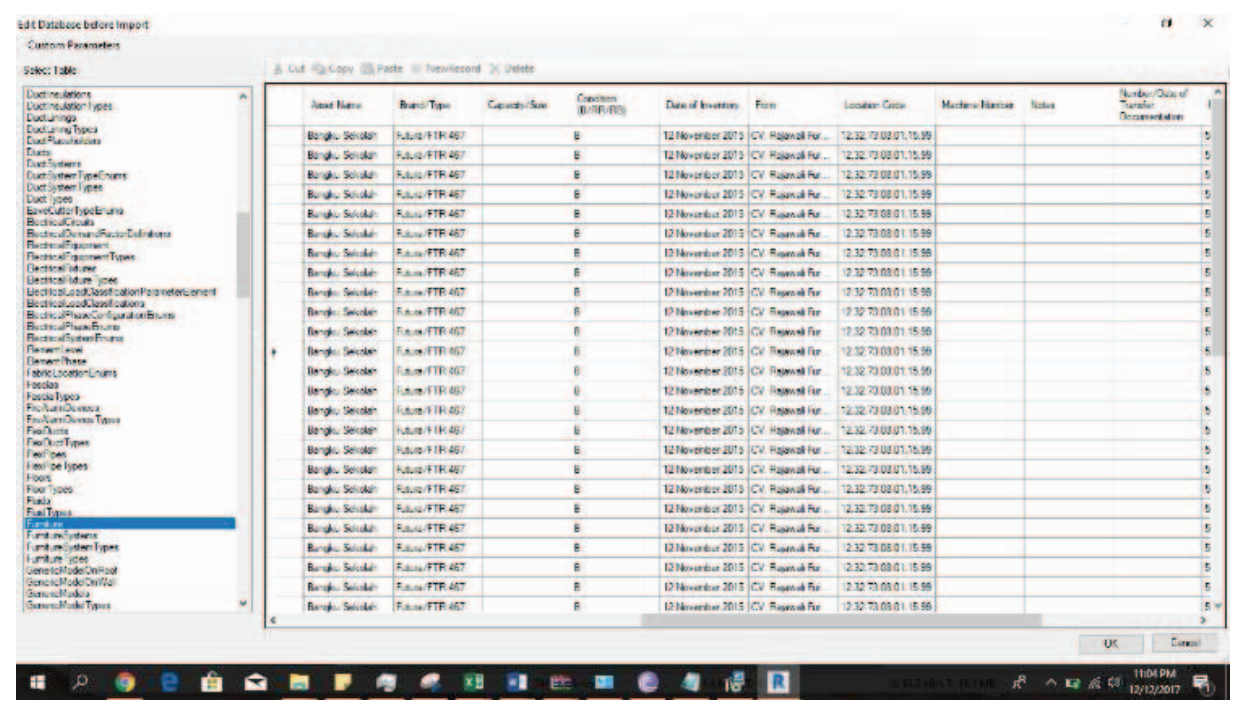

Fig. 26: Database of furniture. 


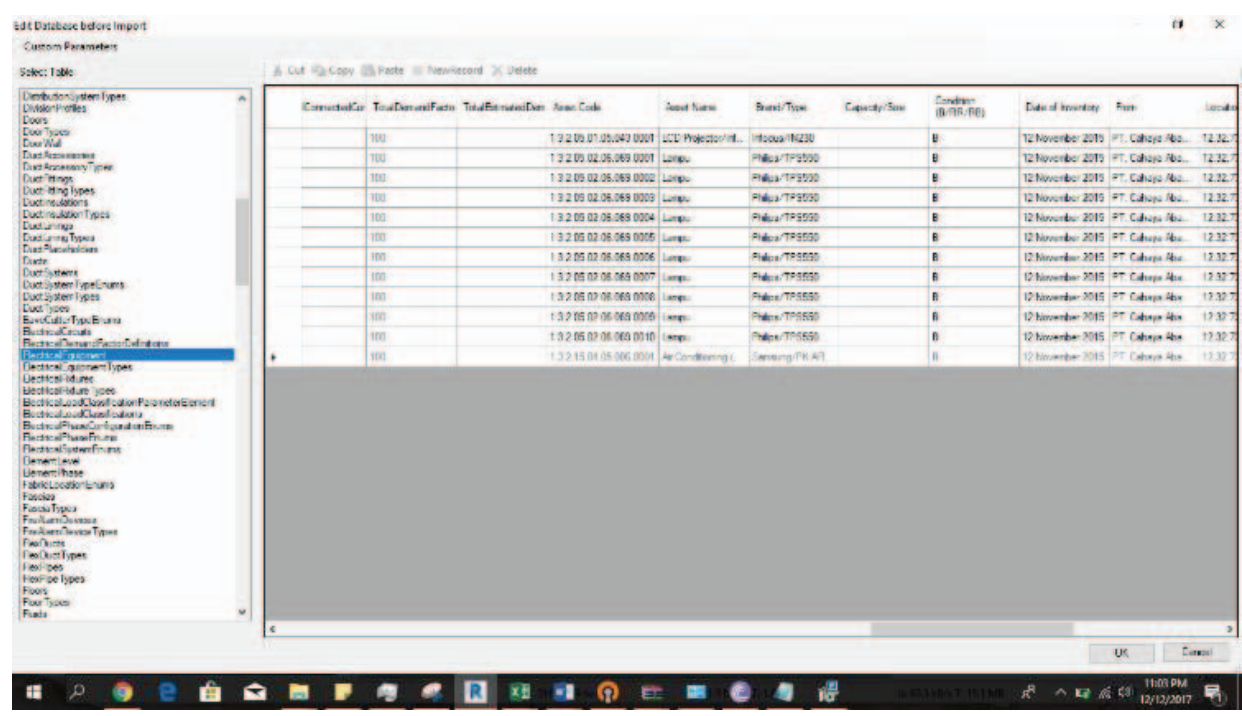

Fig. 27: Database of electrical equipment.
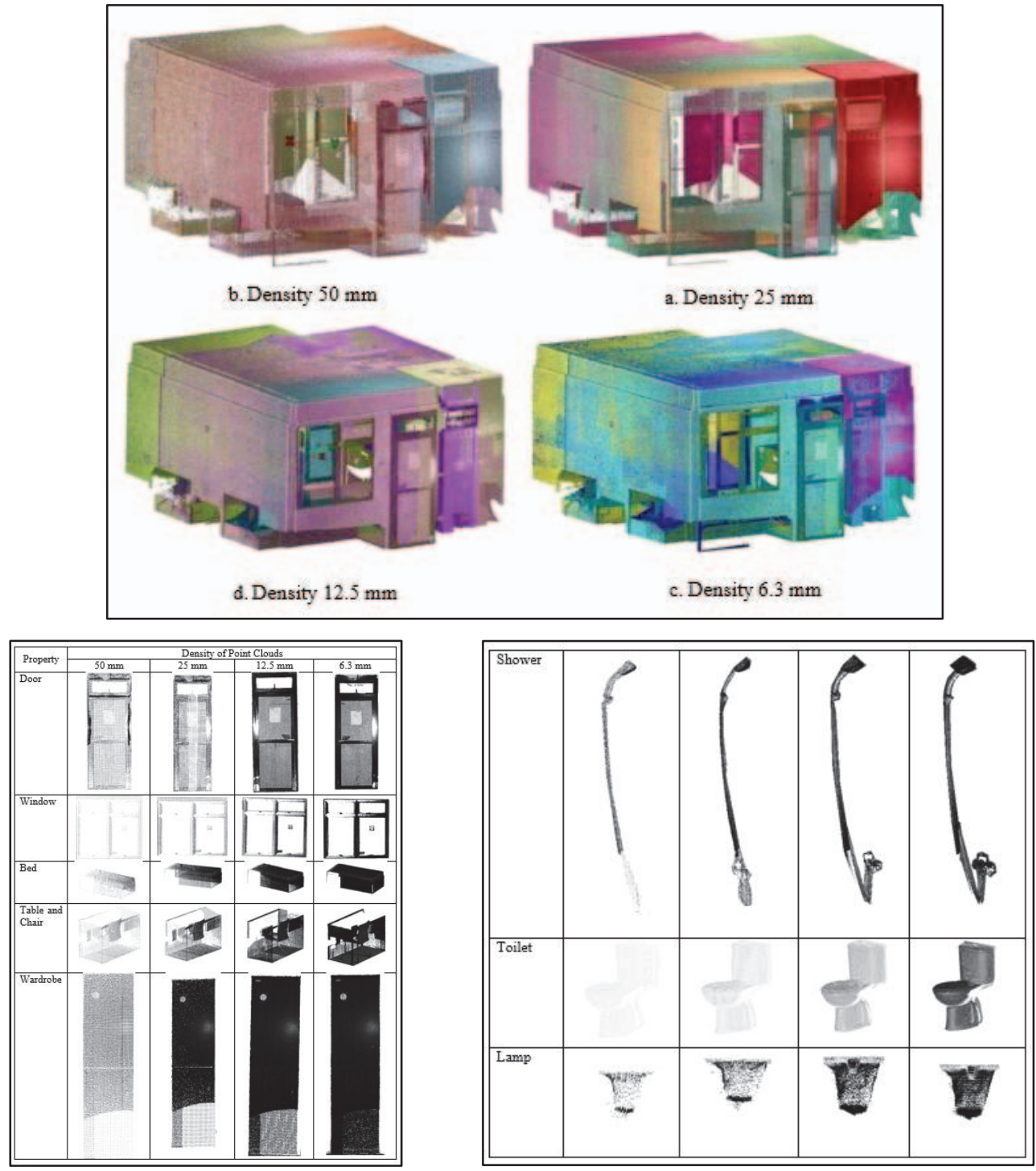

Fig. 28: The results of new research [15]. 
To acquire three-dimensional modelling, TLS must not be used. Three-dimensional modelling can be done by CAD or close range photogrammetry using the camera. But the advantage of TLS is in the accuracy of the position of three-dimensional coordinates, so that the resulting data will be similar to the building in reality and the size is more thorough. The drawback is that the TLS generated data is quite large, and it takes a computer with large RAM.

The advantage for students from this research is to get new knowledge about BIM that is developing in Indonesia and to conduct research related to BIM. For researchers, this research can develop insight and continue research related to BIM, and establish cross-sector cooperation. An example of further research is "Level of Detail Analysis for Property and Building Information Modelling (BIM) Integration". The research is done by comparing the resolution of the TLS shown in Fig. 28 [15]. In professionals, the current benefits of BIM are not too significant, but the use of TLS can be used as a method to model a building or evaluate buildings. can also shorten the time in building modelling.

\section{CONCLUSION}

TLS can be used to obtain three-dimensional position information on buildings or objects. The use of TLS can quickly reach all parts and corners of the building or objects in detail because it is point cloud based. TLS also helps in producing BIM, namely in terms of visualizing the building and assets of the local government. Later BIM can be used to track asset locations, asset value analysis, information support, and building development planning.

\section{ACKNOWLEDGEMENT}

We would like to thank Institute for Research and Community Services of Bandung Institute of Technology for funding this research and also thank to PT. Asaba for lending TLS and giving consultation about operating TLS.

\section{REFERENCES}

[1] Sugiama AG. (2013) Manajemen Aset Pariwisata. Bandung, Guardaya Intimarta.

[2] Mardiasmo. (2005) Akuntansi Sektor Publik. Yogyakarta, Penerbit Andi, 2005.

[3] Crotty R. (2012) The Impact of Building Information Modelling: Transforming Construction, London, SPON Press.

[4] NBS. (2016) International BIM Report 2016, Newcastle.

[5] Eastman C. (2011) A Guide to Building Information Modelling for Owners, Managers, Designers, Engineers, and Contractors. New Jersey, John Wiley \& Sons.

[6] Randall T. (2013) Client Guide to 3D Scanning and Data Capture. London, United Kingdom, UK BIM Task Group.

[7] Quintero MS, Genechten BV, Bruyne MD, Ronald P, Hankar M, Barnes S. (2008) Theory and Practice On Terrestrial Laser Scanning, Valencia, Universitat Politècnica de València Editorial

[8] Topcon Laser scanner GLS-2000 Instruction Manual [http://www.topcon.co.jp/en/ positioning/products/pdf/GLS-2000_E.pdf]

[9] BIMForum. (2016) Level of Development Specification. United States.

[10] NBIS. (2015) National BIM Standard-United States Version 3. Washington D.C.

[11] Demchak G, Krygiel E, Dzambazova T. (2009) Introducing Revit Architecture 2010: BIM for Beginners. New Indiana, Wiley Publishing, Inc.

[12] Kreider RG, Messner JI. (2013) The Uses of BIM: Classifying and Selecting BIM Uses. Pennsylvania, The Pennsylvania State University, University Park. 
[13] Maptek. (2015) Training Manual I-Site Studio Version 6.0. Australia

[14] Bagaskara D. (2017) Pemodelan 3D Aset dalam Bangunan Berbasiskan Building Information Modelling (BIM) Menggunakan Data Terestrial Laser Scanner (TLS). Bandung, Bandung Institute of Technology.

[15] Saptari, AY, Hendriatiningsih S, Hernandi A, Sudarman, Rahmadani P, Saragih D. (2018) Level of Detail Analysis for Property and Building Information Modelling (BIM) Integration. Bandung, Bandung Institute of Technology. 